\title{
Reliance of the Saudi Youth on Social Media as a Source of Information about Al-Hazem Storm
}

Amer Aldahmashi F*

Faculty of Arts, Department of Communication and Media, King Faisal University, Saudi Arabia

\begin{abstract}
This study examines the Saudi reliance on social media as a source of information about the military operation known as Al-Hazem Storm. In addition, the study seeks to understand the factors that affect the reliance of young people on such media and their satisfaction when dealing with these networks during Al-Hazem Storm. The researcher used the analytical descriptive method and a questionnaire as instruments to cover the applied part of the study, which was constructed for the purposes of the study according to the well-known scientific steps as it was applied on a sample that consisted of (151 terms) used by young Saudis during the second academic semester (2016-2017). The study concluded that social media ranks on the top resources on which young Saudis rely when following Al-Hazem Storm and in terms of their satisfaction with the role of social media, the use of such sources having become a vital aspect of the life of the Saudi community.
\end{abstract}

Keywords: Al-Hazem Storm; Social media; Information resource; Saudi youth; Theory of reliance

\section{Introduction}

Modern media have become increasingly important [1]. They have become more complex and multi-dimensional in forming public opinion, influencing the political opinions of individuals and guiding their behaviour. Moreover, through virtual transmission modern media - especially social media - are able to guide individuals easily at lower cost [2]. In addition, they have become more capable of enabling them to express their opinions and criticisms directly, not to mention contributing to making dangerous and complex changes in political life. In this context, as of the year 2014, the total numbers of all kinds of devices which are connected with the mobile have surpassed the world's population [3]. It is expected that the number will reach 1.5 devices per human being by 2019. However, the rapid appearance of new shapes and forms of computerised device has not stopped anywhere, and the same applies to smart/white board, fablitice, smart TVs and smart watches. This represents a developmental step towards computerisation everywhere. In fact, the spread of smart phones has resulted in the rapid spread of news transmission through social media that can be navigated though mobiles [4]. Since the start of the military operation called Al-Hazem Storm in Yemen by the Arab Allied Troops under the leadership of the KSA, all Arab and foreign media (especially the Arabic speaking ones) - whether in support of the war or opposed to it - in concentrated media coverage of what was going on in Yemen and in covering the results of shelling operations [5]. The media are the main source from which the audience gets information about these events - especially under conditions of instability and struggle, violence, disasters and crisis - and finds suitable explanations for them. Accordingly, this requires a more active role by such means as media management owing to the size and content of information presented to the audience [6]. In this context, the events of Al-Hazem Storm are considered among the most important ones and have attracted the attention of the media in general and journalism in particular during the period 26/3/2015 until 22/4/2016, as these events have occupied the focused attention of the media, despite the variations in perspective, with differences in the reactions to them [7]. Since the first hours after announcing the start of Al-Hazem Storm by the allied coalition of ten under the leadership of the Kingdom of Saudi Arabia, against the group of Ansar Allah-Hothyeen in Yemen, E-media and social media have shown the reactions towards the strike and its objective and its results [8]. Therefore, the users of social media (Facebook, Twitter, YouTube) began publishing news of the air raids and exchanging videos of these raids as well as exchanging the statements of countries participating in the coalition [9]. This was during the first day of the raids, while the reactions of the users of social media began to crystallise on the second day of the air raids [10].

Most Twitter and Facebook users considered that the purpose of the military operation in Yemen was not merely to ensure the safety of that country, but to counter the multi arms Iranian incursion in the Arab region, which is deemed as a real danger to Arab interests, as the battle with the Houthis represents the first real battle between Saudi Arabia and Iran in addition, the military operation seeks to protect the safety of the Gulf, as it is threatened by Iranian support for the Houthis in Yemen [11].

In this regard, the previous studies showed a reliance on the traditional media, such as TV, radio stations, newspapers and magazines under the shelter of crisis $[1,12]$. However, during the last few years, the internet has come to be the main means of communication in the Kingdom of Saudi Arabia [13]. Few Arabic studies have been conducted among young Saudis concerning their reliance on social media as a source of information about Al-Hazem Storm. However, the study by Aadil Bin Abdulqadir Al-Maknizi attempted to diagnose the media coverage of Al-Hazem Storm in the Saudi electronic media and the extent of its consistency with the media framework on which the professional practices of those newspapers rely, while confirming the extent of E-media interaction and audience during the occurrence of events and the emergent crisis.

*Corresponding author: Faculty of Arts, Department of Communication and Media, King Faisal University, Saudi Arabia, Tel: +966-35808573; E-mail: aldahmashif@gmail.com

Received July 17, 2017; Accepted September 15, 2017; Published September 18,2017

Citation: Amer Aldahmashi F (2017) Reliance of the Saudi Youth on Social Media as a Source of Information about Al-Hazem Storm. J Mass Communicat Journalism 7: 346. doi: 10.4172/2165-7912.1000346

Copyright: (@ 2017 Amer Aldahmashi F. This is an open-access article distributed under the terms of the Creative Commons Attribution License, which permits unrestricted use, distribution, and reproduction in any medium, provided the original author and source are credited. 
The study concluded that there were no significant statistical differences between the topics of media coverage between those handled by Al-Riyadh newspaper and the topics covered by Middle East newspapers, with differences in the method of handling media writing coverage in both newspapers in addition to significant statistical differences between information sources used by Al-Riyadh newspaper and the ones used by Middle East newspapers as well differences between the interactions of the audience with both newspapers [12].

\section{Problem of the Study}

Due to the increasing interest in studying the dimensions of reliance relationships with the media and the effects that may result from such reliance, the problem of the study can be defined as understanding the reliance of Saudi youth on social media as a source of information about Al-Hazem Storm, and in determining the factors affecting their reliance on such networks and their satisfaction when dealing with these networks during Al-Hazem Storm.

\section{Significance and objectives of the study}

This study represents a new dimension in detecting the nature of the relationship between the audience and social media since it explores one of the most important topics in modern media studies, which is deemed as a new scientific addition to the field of media influence on the knowledge and attitudes of the audience. Few scientific studies have examined the reliance of young Saudis on social media when obtaining security, political and military information and there is a need to know the uses of social media, especially in the political field. In this regard, most studies have concentrated on the reasons for using the internet in general as a means of communication. Accordingly, this study aimed to examine the extent of reliance among young Saudis on social media to follow Al-Hazem Storm.

\section{Questions of the study}

1. Which media were used to follow Al-Hazem Storm?

2. What is the extent of the sample's follow-up in using social media during Al-Hazem Storm?

3. What are the reasons for following Al-Hazem Storm through social media?

4. What are the attitudes of young people to what social media disseminate about Al-Hazem Storm?

5. What were the most important issues of Al-Hazem Storm that were followed?

6. What have been the most influential new media networks during the events of Al-Hazem Storm?

\section{Methodology}

This study depends on the method of survey of a sample as one of the descriptive methods that can investigate the current facts, which are relevant to the nature of the phenomenon in order to gain full and accurate information. This method is the main methodology to study the audience of the media; it helps in understanding the attitudes, opinions and feelings of the audience in terms of popular topics and issues not to forget the surveys that intend to examine the extent of media influence.

\section{Instrument of the Study}

The field questionnaire was used to cover all the objectives of the study, through a series of open-ended and closed questions as well as various measurements.

\section{Population and Sample of the Study}

The population of the field study is young Saudis who interact with social media, and a sample of (151 terms) was taken from among young Saudis.

\section{Results of the Study}

From the above table it is clear that social media rank top in the sources of media that are used by young Saudis to in follow Al-Hazem Storm (64\%) (Table 1).

In addition, it is clear that young Saudis rely on the Saudi media (whether electronic or traditional) more than the Arab and foreign media; $38 \%$ of them rely on Saudi websites, followed by Saudi satellite stations (34.7\%) then Saudi newspapers (24\%) (Table 2).

The data in the above table show that almost half of the sample (52\%) follow Al-Hazem Storm through social media (among them 20\% follow it "daily" and 32\% follow it sometimes "from 3-6 days a week", while $48 \%$ of young Saudis rarely follow it "less than 3 days a week" (Table 3).

Regarding the reasons for following Al-Hazem Storm through social media, $46 \%$ of young Saudi respondents indicated that it can be attributed to the characteristics of social media in terms of "fast and renewed news", while $13.3 \%$ mentioned that they provide: comprehensive and complete information. On the other hand, $11.3 \%$

\begin{tabular}{|l|c|c|}
\hline Category & No. & $\%$ \\
\hline Saudi Electronic websites & 57 & 38 \\
\hline Arab electronic websites & 16 & 10.7 \\
\hline Foreign electronic websites & 2 & 1.3 \\
\hline Saudi satellite stations & 52 & 34.7 \\
\hline Arab satellite stations & 18 & 12 \\
\hline Foreign satellite stations1 & 1 & 0.7 \\
\hline Saudi newspapers & 36 & 24 \\
\hline Arab newspapers & 9 & 6 \\
\hline Foreign newspapers & 1 & 0.7 \\
\hline Social media & 96 & 64 \\
\hline
\end{tabular}

Table 1: Answer to the first question: the media means used to follow Al-Hazem Storm.

\begin{tabular}{|l|c|c|}
\hline Category & No. & $\%$ \\
\hline Seldom & 72 & 48 \\
\hline Sometimes & 48 & 32 \\
\hline Always & 30 & 20 \\
\hline
\end{tabular}

Table 2: Answer to the second question: to what extent do people follow the course of Al-Hazem Storm through social media?

\begin{tabular}{|l|c|c|}
\hline Category & No. & $\%$ \\
\hline There news are fast and renewed news & 69 & 46 \\
\hline More credible than other media & 16 & 10.7 \\
\hline Does not depend on provoking & 3 & 2 \\
\hline $\begin{array}{l}\text { Their information is comprehensive and } \\
\text { complete }\end{array}$ & 20 & 13.3 \\
\hline Their sources are definite and well-known & 12 & 8 \\
\hline $\begin{array}{l}\text { Gives me freedom to express my opinion } \\
\text { and exchange perspectives }\end{array}$ & 17 & 11.3 \\
\hline Uncovers the general attitudes of people & 13 & 8.7 \\
\hline
\end{tabular}

Table 3: Answer to the third question: reasons for following Al-Hazem Storm through social media. 


\begin{tabular}{|c|c|c|c|c|c|c|}
\hline \multirow[t]{2}{*}{ Category } & \multicolumn{2}{|c|}{ Agree } & \multicolumn{2}{|c|}{ Neutral } & \multicolumn{2}{|c|}{ Opponent } \\
\hline & No. & $\%$ & No. & $\%$ & No. & $\%$ \\
\hline Show what other media don't show(newspapers and TV) & 89 & 59.3 & 48 & 32 & 13 & 8.7 \\
\hline Publish false news & 46 & 30.7 & 60 & 40 & 44 & 29.3 \\
\hline Not everything which is published is correct & 82 & 54.7 & 57 & 38 & 11 & 7.3 \\
\hline
\end{tabular}

Table 4: Answer to the fourth question: the attitudes of the young to what social media publish about Al-Hazem Storm.

\begin{tabular}{|l|c|c|}
\hline Category & No. & $\%$ \\
\hline Social media networks & 85 & 36.17 \\
\hline News websites & 52 & 22.13 \\
\hline Services through mobiles & 95 & 40.43 \\
\hline Twitter & 3 & 1.28 \\
\hline
\end{tabular}

\begin{tabular}{|l|c|c|}
\hline Category & No. & $\%$ \\
\hline Our soldiers on the southern borders & 126 & 84 \\
\hline Arab allied troops operations & 39 & 26 \\
\hline The Yemeni government & 7 & 4.7 \\
\hline The Yemeni troops & 8 & 5.3 \\
\hline $\begin{array}{l}\text { Countering the Houthis and the supporters } \\
\text { of Ali Abdullah Saleh }\end{array}$ & 32 & 21.3 \\
\hline The political and relief efforts of the KSA & 48 & 32 \\
\hline The human situation in Yemen & 50 & 33.3 \\
\hline
\end{tabular}

stated that the reasons for following Al-Hazem Storm were that they provide freedom of expression, opinion and perspectives, whereas $10.7 \%$ considered it (social media) as more reliable than other media. However, the other categories gained fewer percentages than those above (Table 4).

Regarding the attitudes of the young in terms of what is written on social media about Al-Hazem Storm, most participants (59.3\%) felt that social media show what other media do not present (newspapers and TV), whereas $32 \%$ were neutral and $8.7 \%$ were opposed.

In terms of publishing false news, the perspectives of young Saudis varied, as $40 \%$ were neutral and the other percentages were distributed between supporters and opponents. More specifically, 54.7\% felt that not everything which was published was correct due to the spread of rumours, especially those promoted by opponents, or people on Twitter who could not distinguish between the weak and the good. On the other hand, $38 \%$ were neutral and $7.3 \%$ were opposed (Table 5).

The media service through the mobile surpassed social media as it came in the first rank among the new media means which affect dealing with information during the events of Al-Hazem Storm (40.43\%, followed by social media $36.17 \%$, then news websites). Twitter was the least influential in dealing with information during the events of $\mathrm{Al}$ Hazem Storm (a maximum of 1.28\%) (Table 6).

From the data in the above table it is clear that the most important issues that were followed by the respondents through social media were the Saudi soldiers on the southern borders (40\%) due to their desire to know the news of their relatives and citizens on the front, then to know the human situation in Yemen (33.3\%) which confirms the importance of the human dimension, followed by the political and relief efforts of the Kingdom of Saudi Arabia, whether on the relief level or the political movements. This was followed by the operations of the Arab allied troops (26\%) and countering the Houthis and supporters of Ali Abdullah Saleh (21.3). The remaining issues gained fewer percentages. From the above, it is clear that young Saudis follow the human and social issues, followed by the political and military issues.

\section{Discussion}

The reasons for the first rank of social media used by young Saudis in following Al-Hazem Storm can be attributed to the fact that the needs and desires of individuals for information have increased in light of the crisis. Especially when the traditional media means cannot satisfy such needs, audiences are forced to search for other sources that give them access to information to achieve their objectives.

With the rapid development and spread of social media, they have

Table 6: Answer to the sixth question: the most important issues of Al-Hazem Storm that were followed.

become an important alternative channel that allows the audience (especially the young) to gather information. Accordingly, this study is consistent with Ball, Gall-Rokeach, Rokeach and Loges, Kim and Jung. During a serious crisis, the young become more dependent on social media. Furthermore, young Saudis become more dependent on the Saudi media (whether electronic or traditional) and see these as superior to the Arab and Western media since they handle issues from a local perspective. The lack of significant statistical differences between males and females in following social media during Al-Hazem Storm and other media means the were used during Al-Hazem Storm, with the level of satisfaction for the rule of social media in KSA where there is no influence on gender variable. In this vein, such use has become a main aspect of the life of the Saudi community and increases from one time to another.

In addition to this, the absence of significant statistical differences between the respondents according to the age variable, due to the variation of media means that satisfy the interests and needs of young Saudis is attributed to the elderly perspective on social media (who were less satisfied than the young) who lack good experience which enables them to judge social media in such a good way.

\section{Most important results}

Social media have become an important channel on which young Saudis rely to follow Al-Hazem Storm, with the absence of significant statistical differences between males and females in their reliance on social media during the events of Al-Hazem Storm, as well as in the media means that were used in following the events of Al-Hazem Storm. In this regard, such use has become a major aspect of the life of the Saudi community and continues to increase over time.

\section{Recommendations}

1. Ascertain the density of using the Saudi youth for social media during the events of Al-Hazem Storm.

2. Examine the factors affecting the reliance of young Saudis on social media during the events of Al-Hazem Storm and the nature of their interaction with such networks.

3. Examine the extent among the young of satisfaction with the handling by social media of Al-Hazem Storm.

4. Conduct more studies into how young people gather information through social media. 
Citation: Amer Aldahmashi F (2017) Reliance of the Saudi Youth on Social Media as a Source of Information about Al-Hazem Storm. J Mass Communicat Journalism 7: 346. doi: 10.4172/2165-7912.1000346

\section{References}

1. Loges WE (1994) Canaries in the coal mine: Perceptions of threat and media system dependency relations. Communication Research 21: 5-23.

2. CISCO (2015) Cisco Visual Networking Index: Global Mobile Data Traffic Forecast Update 2014-2019 White Paper. Digital4EU

3. Lyytinen KJ, Yoo Y, Varshney U, Ackerman M, Davis G, et al. (2004) Surfing the next wave: design and implementation challenges of ubiquitous computing. Commun Assoc Inf Syst 13: 697-716.

4. Vodanovich S, Sundaram D, Myers M (2010) Research commentary - digital natives and ubiquitous information systems. Inf Syst Res 21: 711-723.

5. Carillo K, Scornavacca E, Za S (2014) An investigation of the role of dependency in predicting continuance intention to use ubiquitous media systems: combining a media system perspective with expectation-confirmation theories, pp: 1-17.

6. Scornavacca E, Barnes SJ, Huff SL (2006) Mobile business research published in 2000-2004: emergence, current status, and future opportunities. Communications of the Association for Information Systems 17: 635-646.
7. Yuan, Archer N, Connelly CE, Zheng W (2010) Identifying the ideal fit between mobile work and mobile work support. Inf Manag 47: 125-137.

8. Sorensen C (2011) Enterprise Mobility: Tiny Technology with Global Impact on Work. Technology, Work and Globalization, Palgrave Macmillan.

9. Chen L, Meservy TO, Gillenson M (2012) Understanding information systems continuance for information-oriented mobile applications. Commun Assoc Inf Syst 30: 127-146.

10. Mallat N, Rossi M, Tuunainen VK, Öörni A (2009) The impact of use contex on mobile services acceptance: the case of mobile ticketing. Information and Management 46: 190-195.

11. Stafford TF, Belton M, Nelson T, Peevyhouse A (2010) A. Peevyhouse Exploring dimensions of mobile information technology dependence.

12. Lowrey W (2004) Media dependency during a large-scale social disruption: The case of September 11.

13. Tai Z, Sun T (2007) Media dependencies in a changing media environment: The case of the 2003 SARS epidemic in China. New Media and Society 9 987-1009. 